\title{
Seeking the 'point of no return' in the sequence of events leading to mortality of mature trees
}

\author{
Yakir Preisler ${ }^{1}$, Fedor Tatarinov ${ }^{1}$, José Grünzweig ${ }^{2}$, and Dan Yakir ${ }^{1}$ \\ ${ }^{1}$ Weizmann Institute of Science \\ ${ }^{2}$ Hebrew University of Jerusalem Robert H Smith Faculty of Agriculture Food and \\ Environment
}

September 11, 2020

\begin{abstract}
Drought-related tree mortality is increasing globally, but the sequence of events leading to it remains poorly understood. To identify such sequence, we used a 2016 tree mortality event in the semi-arid pine forest of Yatir were dendrometry and sap flow measurements were carried out in 31 trees, of which seven died. A comparative analysis revealed three stages leading to mortality. First, a decrease in tree diameter in all dying trees, but not in the living ones, eight months "prior to the visual signs of mortality' (PVSM; e.g., brown needles). Second, a decay to near zero in the diurnal stem swelling/shrinkage dynamics, reflecting the loss of stem radial water flow in the dying trees, six months PVSM. Third, cessation of stem sap flow three months PVSM. Eventual mortality could therefore be detected long before visual signs are observed, and the three stages identified here demonstrated the differential effects of drought on stem growth, water storage capabilities, and soil water uptake. The results indicated that breakdown of radial stem water flow and phloem functionality is a critical element in defining the 'point of no return' in the sequence of events leading to mortality of mature trees.
\end{abstract}

Seeking the 'point of no return' in the sequence of events leading to mortality of mature treesYakir Preisler ${ }^{* 1,2}$, Fedor Tatarinov ${ }^{1}$, José M. Grünzweig ${ }^{2}$, and Dan Yakir ${ }^{1}$

1Earth and Planetary Science Department, Weizmann Institute of Science, Rehovot, Israel; 2Robert H. Smith Faculty of Agriculture, Food and Environment, The Hebrew University of Jerusalem, Rehovot, Israel.

\section{Running head: Mortality sequence of mature trees under drought}

\begin{abstract}
Drought-related tree mortality is increasing globally, but the sequence of events leading to it remains poorly understood. To identify such sequence, we used a 2016 tree mortality event in the semi-arid pine forest of Yatir were dendrometry and sap flow measurements were carried out in 31 trees, of which seven died. A comparative analysis revealed three stages leading to mortality. First, a decrease in tree diameter in all dying trees, but not in the living ones, eight months 'prior to the visual signs of mortality' (PVSM; e.g., brown needles). Second, a decay to near zero in the diurnal stem swelling/shrinkage dynamics, reflecting the loss of stem radial water flow in the dying trees, six months PVSM. Third, cessation of stem sap flow three months PVSM. Eventual mortality could therefore be detected long before visual signs are observed, and the three stages identified here demonstrated the differential effects of drought on stem growth, water storage capabilities, and soil water uptake. The results indicated that breakdown of radial stem water flow
\end{abstract}


and phloem functionality is a critical element in defining the 'point of no return' in the sequence of events leading to mortality of mature trees.

Keywords: Dendrometer, Drought, Dying, Early-signs, Phloem functioning, Radial water flow, Re-watering, Stem, Xylem.

*Corresponding author: ypreisler@fas.harvard.edu

\section{Introduction}

Global climatic trends in previous decades have shown a rise in temperatures and drought intensity, leading to the increased vulnerability of forests and tree mortality events in various biomes (Breshears et al. , 2009; Allen et al. , 2010, 2015; Preisler et al. , 2019). Tree mortality and canopy dieback can be traced directly to water shortages, as well as to secondary stress factors, such as insect damage (McDowell, 2011). Widespread forest mortality has consequences for global carbon, water, and energy fluxes (McDowell et al. , 2008; Adams et al. , 2012; Bastinet al. , 2017; Pugh et al. , 2019). Despite the significant impacts of trees on the global biogeochemical cycles, the series of physiological responses to drought before, during, and after a tree mortality event are unknown-inflating uncertainty in the future of our forests. Thus, understanding, quantifying, and detecting the tree mortality sequences, from an ecophysiological perspective, is urgently required.

Two physiological mechanisms leading to tree mortality are hydraulic failure (embolism) and carbon starvation, which have been investigated in many previous studies over the past decade (McDowell et al. , 2008; Sala et al. , 2010; Choat et al. , 2012; Hartmannet al. , 2013; Sevanto et al., 2014; Hartmann, 2015; Meiret al. , 2015; Adams et al. , 2017; Cailleret et al. , 2017; Kono et al. , 2019). Identifying early warning indicators to determine when trees cross the 'point of no return', beyond which mortality is inevitable, has been a major focus of recent studies, which highlight plant water content, leaf wilting, and loss of hydraulic conductivity as key parameters (Anderegg et al. , 2012; Hartmannet al. , 2018; Hammond et al. , 2019; Sapes et al. , 2019). Experimental manipulations have largely been conducted on young trees (e.g., seedlings, saplings) in controlled conditions measuring physiological responses such as percent loss of conductivity (PLC), water potential $(\Psi)$, and nonstructural carbohydrates (NSC), while large-scale observations (e.g., remote sensing) have focused on foliar color, GPP, etc. (Ogaya et al. , 2015; Schwantes et al. , 2016; Paz-Kagan et al. , 2018). There are only few studies on mature trees - mainly due to logistic constraints; yet such studies are likely to be the most important for understanding/predicting forest mortality events in relation to future climate. Physiological indicators and thresholds of vulnerability to drought may be similar or differ quite considerably among species. Yet, the progression of the risk of mortality is likely related to the coordination of many plant traits, rather than a single trait (Hammond \& Adams, 2019; Blackman et al., 2019). Furthermore, the resistance in different species to drought stress is also related to their anatomy and physiology. While some species are expected to have minimal recovery after crossing their $\Psi$ associated with $50 \%$ loss of xylem conductivity (P50) (Brodribb \& Cochard, 2009), many conifers have been observed to survive 90 $\%$ loss of conductivity (Tyree \& Sperry, 1988; McCulloh \& Woodruff, 2012; Klein et al. , 2016a; Hammond et al. , 2019). The progression of tree mortality risk can be related to different traits, such as stomatal control (Delzon \& Cochard, 2014; Martin-StPaulet al. , 2017), the use of internal water storage (Steppe et al. , 2015; Colangelo et al. , 2017), cuticular water loss (Cochard, 2019), NSC availability and mobility, and phloem transport (Sala et al. , 2012; Klein et al. , 2014a; Sevanto et al. , 2014; Hoch, 2015; Savage et al. , 2016; Wiley et al. , 2017).

Recovery from embolism occurs during the radial growth of new sapwood (conductive xylem) that replaces the old embolized xylem (Hammondet al. , 2019). Growing new conductive areas requires both available carbon and a well-functioning phloem (De Swaef et al. , 2015; Steppe et al. , 2015). This link between the xylem hydraulic state and the functioning of the phloem is also expressed in the daily stem diameter changes caused by radial water transport from the living bark and phloem tissues to the transpiration stream, following the water potential gradient between these neighboring tissues (Zweifel et al. , 2001; Daudet et al. , 2005; Hölttä et al. , 2006, 2009; De Schepper \& Steppe, 2010; Sevanto et al. , 2011, 2014; Steppe 
et al. , 2015). Diameter variations are driven by differences in xylem water potentials and phloem osmotic concentrations (Hölttä et al. , 2009; Sevanto et al. , 2014). Diurnal variations in stem diameters resulting from radial water flow between xylem and phloem have been used for physiological assessments and modeling efforts (Sevanto et al. , 2011; De Swaef et al. , 2015). Diurnal fluctuations in diameter originate mainly from the shrinkage and swelling of the living phloem and bark tissues (70-90\% of the total diurnal fluctuations), with the remaining contribution $(30-10 \%)$ from the xylem. Some studies show a higher proportion of the daily fluctuations are from the xylem (> $30 \%$ of the total) (Sevanto et al. , 2002; Zweifel et al. , 2014), but in most cases, the phloem and bark are the major contributors (>50 \%) (see e.g. Cermak and Nadezhdina, 1998; Irvine and Grace, 1997; Scholz et al., 2008).

This hydraulic link between xylem and phloem supports phloem transport under well-watered conditions but limits it under dry conditions when xylem tensions increase (Hölttä et al. , 2009). Phloem tissues also act as a water reservoir for transpiration, buffering high transpiration demands during the dry season, thus promoting tree survival (Zweifel \& Häsler, 2000; Pfautsch et al. , 2015a) and growth (Hölttä et al. , 2010; Coussement et al. , 2018). Direct damage to the phloem via insects or pathogenic attacks will reduce the phloem's ability to transport and allocate sugars (Schultzet al. , 2013), potentially resulting in growth declines or increased risk of tree death probably as a result of alterations of phloem transport as a response to drought (Salmon et al. , 2019). Nonetheless, the direct effects of phloem damage to the xylem (in particular to the sap flow), are still unclear (Savage et al., 2016; Salmon et al. , 2019).

While knowledge of the physiological mechanisms of tree mortality and their sequences have been investigated in controlled experimental conditions, it is unknown how mature trees in forests may differ in their responses. The objectives of this study were: 1) to identify the 'point of no return' in mature trees exposed to a severe drought (or water limitation); and 2) to improve our understanding of the traits involved in the tree mortality sequence. These objectives were addressed by using high-resolution physiological measurements of both xylem and phloem hydraulic status. For these purposes, we monitored stem diameter changes using band dendrometers (Sevanto et al. , 2014; Zweifel, 2016) and water uptake with sap flow sensors.

The radial growth and sap flow of the 50-year-old Aleppo pine (Pinus halepensis ) trees growing in the world's driest pine forest $(\mathrm{P} / \mathrm{PET}=0.17)$ in Yatir (a FLUXNET site), have been measured continuously since 2009 (Klein et al., 2016; Tatarinov et al., 2016). In the spring of 2016, mortality was observed among the sampled trees, with visual indicators of tree death (brown and dry needles) beginning in April 2016. Here, we describe the physiological events leading to tree mortality in the mature Aleppo pine trees grown in the semi-arid forest and demonstrate the link between phloem and xylem water transport under drought conditions. The natural conditions of this study site, which constitutes long and harsh dry period and short and concentrated rainy period, together with the ongoing measurements enabled us to investigate the potential processes that define the 'point of no return' in the mortality sequence of mature trees.

\section{Methods}

Experimental site

The study was conducted in the Yatir forest, located near the northern edge of the Negev desert (31@20'N, $35^{\mathrm{O}} 03$ 'E, 550-700 $\mathrm{m}$ above sea level). This forest, planted mainly in the mid-1960s, is dominated by Aleppo pine (Pinus halepensis Mill.) and covers an area of about 3000 ha. Current stand density is ${ }^{\sim} 300$ trees ha $^{-1}$, with a deep and unreachable ground-water table $(>-300 \mathrm{~m})$. The soil type is classified as light Rendzina (Haploxeroll) above chalk and limestone. The climate is Mediterranean with prolonged summer drought periods from May to October (average daily temperature in July is $25 @ \mathrm{C}$ ) and a winter period with low levels of precipitation (annual mean is $280 \pm 90 \mathrm{~mm}$ ) and moderate temperatures ( 10 @C in January), (Grünzweig et al. , 2007; Rotenberg \& Yakir, 2010).

Tree physiology

Tree sap flow (SF) was continuously measured since 2012 in 31 trees, by home-made heat dissipation sensors (Granier, 1985) with site and species specific adjustments (Appendix 1, Cohen et al. , 2008; Kleinet al. , 
2014b). Variations in stem diameter at breast height (DBH; $1.3 \mathrm{~m}$ height)) were measured by automatic band dendrometers (EMS, Brno, Czech Republic) in five trees since 2012, and in 20 trees starting in August 2015.

Intensive 16 to 24 -h leaf-scale diurnal measurements were conducted in 13 trees equipped with dendrometers and sap flow sensors in six campaigns from May 2014 to September 2015, 5-7 trees measured in each campaign (Table S1). Measurements were taken every 1.5-2 hours, including twig water potential ( $\left.\Psi_{\text {leaf }}\right)$ using a pressure chamber (PMS Instrument Company, Albany, OR, USA), needle water content, and leaf gas exchange (LI6400, Licor Inc., Lincoln, NE, USA). In total, 12-18 shoots per tree were sampled within each campaign (for detailed methods, see Supplementary information methods).

Mortality event

In the spring of 2016, a mortality event occurred in the study plot where the sap flow and dendrometry measurements were carried out. Visual browning (Figure S1) of the needles was observed in seven trees, starting in April 2016. Bark beetle (Orthotomicus erosus ) presence was observed in five out of the seven dead trees in June-July 2016, with typical galleries and exit holes (Figure S1). Some beetle attacks (mature feeding of top canopy needles) were also observed in the living trees. All seven trees which died during the mortality event had SF sensors, and five had dendrometers. The last diurnal physiological measurements, in August 2015 and September 2015, included eight trees, of which three eventually died in Apr-May 2016 (18 branches were pruned during each campaign, per tree).

Statistical analysis

Measured values from the physiological campaigns were averaged across the sampled trees and sampling hours. For each season, differences between the living and dying trees at each sampling hour (06:00 to 17:00) were analyzed using a paired $t$-test. Piecewise regression analysis was applied to the half-hourly dendrometer data to determine the branching point at which the DBH dynamics of the dying and living trees started to diverge. A paired $t$-test was then used on the two data sets (dying and living trees) for the periods before and after the identified tipping point. Statistical analyses were performed in SigmaPlot12 (Systat Software, Erkrath, Germany) and R (R Core Team (2017) Version 1.1.447 Vienna, Austria.)

\section{Results}

The hydrological years relevant to this study (2013/14, 2014/15, and 2015/16 (October to September in each year) were characterized by above average precipitation, 323, 357, and $349 \mathrm{~mm}$, respectively, and 2016/17 was relatively dry, with $246 \mathrm{~mm}$ of total annual precipitation, compared with the long-term mean value of $285 \mathrm{~mm}$ (data not shown; http://gaia.agraria.unitus.it/home/site-details?id=IL-Yat).

Lack of stem growth as an indication of mortality

The mean annual stem diameter growth (2012-2016) of the Aleppo pine trees in the study site was 2.0 ( \pm 1.4) $\mathrm{mm}$ ( $\mathrm{n}=5$ and 20 , from 2012-2015 and 2015-2016 respectively). Stem growth started after the first rain event (around December) and ceased in April. From April to the next rainy season, trees stem diameters were either relatively stable or shrank up to $0.9( \pm 0.5) \mathrm{mm}$ (Figure 1), depending on the precipitation regime of the preceding rainy season.

No significant differences were found between the seasonal stem diameter trends of the living and dying trees prior to September 2015 ( $\mathrm{p}>0.05$ ). For trees which eventually died, the characteristic phenological trends in stem diameter changed in 2015 (Figure 2). The stem diameter of the dying trees started to decline at the end of the growing season (May 2015), similar to the living trees, but then diverged from the living trees from September 2015 to the end of the record in June 2016 ( $\mathrm{p}<0.001)$. Stem diameter declined in dying trees by $2.2( \pm 0.003) \mathrm{mm}$, but grew by $2.5( \pm 1.4) \mathrm{mm}$ in living trees between September 2015 and June 2016. Notably, in contrast to the living trees, the dying trees did not show any positive response (increase) in their diameter to the onset of the rainy season in December 2015 or to any subsequent rain events. 
Cessation of xylem water transport as an early indication of mortality

Seasonal patterns of sap flow were characterized by maximum values $\left(34.5 \pm 3.1 \mathrm{~L} \mathrm{tree}^{-1}\right.$ day $\left.^{-1}\right)$ in the second half of the rainy season between February and April and minimum values at the end of the dry season around October - November $\left(7.8 \pm 0.6 \mathrm{~L}_{\text {tree }}{ }^{-1}\right.$ day $\left.^{-1}\right)$ (Figure $2 \mathrm{~b}$; Figure s2). The SF in the living and dying trees co-varied until December 2015 when it started to differ. After the first big rain event in January 2016, the SF increased dramatically in the living trees (midday maximum of $2.0 \mathrm{~L} / \mathrm{hr}$ ), whereas in the dying trees, the SF showed only a minor recovery of $0.2 \mathrm{~L} \mathrm{tree}^{-1} \mathrm{hr}^{-1}$ (Figure 2b). From February $2016 \mathrm{SF}$, in the dying trees essentially stopped, with the sensors showing unreliable values (maximum values at midnight, indicating dry wood and thermal artifacts of the sensors).

Evidence of xylem desiccation in the dying trees is supported by increasing temperature differences between the heated and reference probes of the SF sensors, expressed in the voltage readings (dT, mV; Figure 3) from February 2016 to June 2016. When the wood is dry, the ability of transferring the heat generated by the heating probe decreases, resulting in lower heat conductivity and higher $\mathrm{dT}$ in the dying trees. Therefore, in addition to the changes in the SF trend itself, dT depends on the xylem thermal conductivity, which, in turn, depends on the wood water content. The increasing trend in $\mathrm{dT}$ of the dying trees during the period when SF showed a sharp recovery (January-April 2016) in the living trees, strongly indicated a drying trend in the xylem of the dying trees.

Reduction of daily radial stem water flows as an early indication of mortality

Diurnal dynamics of stem diameter provides insights into the radial water fluxes between the phloem and bark to the xylem. The mean (2012-2017) diurnal dynamics of the stem diameter in the rainy season were characterized by a morning maximum at around 08:00 and a minimum at the end of the day at around 17:00 hours (Figure S3). The mean diurnal trend of the live and dying trees was similar until November 2015, when it started to differ significantly both in amplitude and trend (Figure $4 ; \mathrm{p}<0.05$ ).

Another way to present the diurnal fluctuation in stem diameter is the maximum daily shrinkage (MDS; calculated as the difference between diurnal maximum and minimum of the DBH). The MDS shows one value per day and it highlights long term changes along the year. The amplitude of the MDS did not differ significantly between the living and dying trees prior to November 2015 ( $>>0.05$; Figure 5). However, after accumulated precipitation of $37 \mathrm{~mm}$ in November 2015, the MDS began to diverge significantly between the living and dying trees $(\mathrm{p}<0.001)$. Namely MDS in the living trees started to increase, indicating high diurnal fluctuations implying high radial water flow, whereas in the dying trees it remained approximately constant (Figure 5). Notably, the seasonal amplitude of the MDS signal did not clearly correlate with annual precipitation, indicating that other controlling factors are involved, such as rain distribution (see Fig. 5 bottom).

Gas exchange and hydraulic traits prior to mortality

Overall, no consistent physiological differences were found between the living and dying trees during the diurnal campaigns that took place between May 2014 and August 2015 (Table 1), prior to the mortality event. Leaf transpiration and $\Psi_{\text {leaf }}$ were higher in the live trees than in the dying trees in May 2014 ( $\mathrm{P}<$ 0.005 and $<0.001$, respectively; two years prior to mortality), but these differences were not consistent over time. In the diurnal campaign of August 2015 ( 7 months prior to tree decline), daytime needle WC was higher in living than in dying trees $(\mathrm{p}=0.006)$, but note that the sampling day in August 2015 occurred during an extremely hot and dry period, with $\mathrm{VPD}>7 \mathrm{kPa}$, and that this difference between tree types was not observed in the measurement campaign one month later.

\section{Discussion}

In this study, on-going comparative measurements over several seasons in a mature pine forest stand provided the opportunity to reconstruct the development of a drought-induced mortality event when its visible signs appeared. The dying trees in this study had dry brown needles in April-May 2016, but as shown recently 
(Hammond et al. , 2019; Blackman et al. , 2019), needle color is a poor indicator of when a tree dies. It probably occurs after a tree is already past the 'point of no return' leading to its mortality. Identifying the evolution of the mortality process, especially in mature trees, will improve our understanding of key traits to forest resilience and, potentially, management steps to minimize its impact. Obtaining information on the mortality process under natural field conditions is invaluable in complimenting studies of small trees or saplings in controlled environments (e.g., Garcia-Forner et al., 2016; Grossiord et al., 2017; Hammond et al., 2019).

The cascade of tree mortality process

Based on our results we identified three discrete early signs of tree mortality, which could be detectable several months before the visual signs of mortality were observed (Figure 6). The first "early warning" indicator was a decrease in stem diameter, which started in September 2015, 8-9 months prior to any visual signs of mortality. Decreases in stem net diameter can result from a combination of cessation of growth, tissue destruction, and tissue shrinkage due to water loss, all of which can occur during prolonged drought (Fernandez \& Cuevas, 2010; Devine \& Harrington, 2011; Urrutia-Jalabert et al. , 2015). In the Yatir forest site, net stem shrinkage and apparent negative growth are not unusual, usually occurring towards the end of the dry season (September-November). The start of the enhanced stem shrinkage of the dying trees, compared with the living ones, occurred in that period, showing similar initial dry-season trend (in May) and before the clear partitioning between the groups of trees was apparent (in September).

The net stem shrinkage was associated with a significant decrease in diurnal stem diameter fluctuations in the dying trees, which appeared to be the second step identified in the mortality sequence. Here too, because the diurnal amplitude is rather small during the dry season $(<0.1 \mathrm{~mm})$ it did not clearly differ from the live trees before November 2015, when the first rain events triggered the more pronounced daily diameter amplitudes in the living trees. Fluctuations in stem diameter can be a combination of several processes including part of the permanent irreversible stem growth, swelling and shrinking of live tissues, water potential changes in xylem conduits (tension changes), and wood daily thermal expansion (Zweifel, 2016; Zweifel et al. , 2016). The diurnal fluctuations are mainly a result of live tissue radial water flow that support the transpiration stream in the morning hours and rehydrate during the night (Sevanto et al. , 2002; Daudet et al. , 2005; Sevanto et al. , 2011). Therefore, the striking complete stop of the diurnal fluctuations (Fig. 4,5) strongly indicates impediment to the radial flux capacity in the dying trees (see also below).

The crucial role of radial water flow in the 'point of no return' process

Radial water flow, from living tissues (mainly bark and phloem) to the xylem and then to the transpiration stream is a well-known process (Zweifel et al. , 2001; Sevanto et al. , 2011; Pfautschet al. , 2015b) that helps to buffer the high evaporative demand in dry conditions, and reduces the associated drop in xylem $\Psi$ values, which may lead to hydraulic failure (Hölttä et al. , 2009; Sevantoet al. , 2014). Therefore, the ability to draw on stored water within the stem to support the transpiration stream contributes to the likelihood that a tree will survive prolonged drought. In contrast, plants that are unable to exploit this trait might cross their 'point of no return' toward mortality faster (Lamacque et al. , 2020).

Based on our findings we suggest that interruption of the radial flow, as reflected in the MDS decline (Figure $4 \& 5$ ), is irreversible. The trees could not recover from this effect even with re-establishing sufficient water supply (above average annual precipitation), and the large MDS response in the living trees. Furthermore, we suggest also that the results indicate that the capacity for radial water flow is a critical trait for tree recovery from drought, by mainly supporting the recovering water transport in the xylem and, sustaining its hydraulic status, and possibly supporting the production of new xylem (Nardiniet al. , 2017; Hammond et al. , 2019). It is important to stress that at the end of the dry season, under severe drought conditions, diurnal fluctuations in stem diameter mainly reflect radial water flow as the capacity for growth is strongly limited.

Note that the differences in the MDS between the dying and living trees became visible in the data only in November 2015, two months after the net diameter started to diverge, but this could be because the natural 
increase in the live trees MDS was delayed until the first rain events. But it seems clear that the ability to recover from drought stress is also linked on the ability to transfer water radially, as also shown recently in Lavender plants (Lamacque et al. , 2020).

Why did sap flow continue after diurnal fluctuations stopped?

The results demonstrated differential development of the disruption of radial and the sap fluxes. The ability to have active sap flow, two months after the MDS of the dying trees started to diverge from the live trees, is probably due to the renewed water supply from the soil, when the volumetric SWC in the root zone was $>25 \%$ between November 2015 and February 2016 (data not shown). The final or total hydraulic failure (i.e, SF cessation) occurred 2.5 months after the radial water flow cessation was identified. Although embolism was not quantified directly, the gradually drying of the wood (Figure 3) may indicate that air continuously accrued in the stems during these two months when xylem transitioned from at least partially fluid-filled, non-flowing state, to an air-filled, embolized state. The wood drying expressed in the dying trees' dT values may be a good indication for embolism and is supported by the direct link between the increase in dT and the decrease in xylem water content shown in previous studies (Tatarinov et al., 2005; Vergeynst et al. , 2014; Hölttäet al. , 2015). Our results are consistent with the findings of hydraulic failure accumulation during lethal drought events (Tyree \& Sperry, 1989; Borghetti et al. , 1998; Choat et al. , 2012; Anderegg et al. , 2012; Sperry \& Love, 2015), and indications of the redundancy of the xylem (and the production of new xylem) reducing the risk of hydraulic failure due to embolism (Hammond et al. , 2019; Körner, 2019). During the dry season, in a monthly means resolution shown in figure 2, the low SF rates makes the differences between the living and the dying trees hardly detectable. Yet, no clear proof for separation between the living to the dying trees was found until the end of January 2015 when SF values in dying trees became unreliable data (figures $2 \mathrm{~b} \& 3$ ).

Possible non-drought contributions to mortality

No clear evidence or early signs for the coming mortality was observed in the leaf-and branch scale physiological measurements in the two years prior to the visual mortality. This goes in line with the idea that the dying process starts from the stem radial water transport and not from the leaves. The significant pruning that took place during these physiological measurements, for measurement purposes, may have led to some damage to the trees defense system (e.g., resin production) and exposed the trees to biotic damage. However, no link between the branch sampling and mortality could be established, as both living and dying trees were sampled to the same extent throughout the study. The higher transpiration and $\Psi$ values in May 2014, in the dying trees (Table 1) were probably not an indication of the early signs of mortality, since it was measured two years before mortality, and because such differences were not observed subsequently.

The clear MDS and diameter decline discussed above, might also reflect damage to the bark and phloem tissues by pathogens. Indeed, the drought period was followed by a bark beetle attack at the site. However, we note that the time of the onset of the bark beetle attack was not known and it could be a consequence of the stress effects and weakening of the tree (Dobbertin et al. , 2007; Preisler et al. , 2019), rather than its cause. Furthermore, our qualitative assessment of the bark beetle damage indicated that its effects were similar in the living and dying trees and therefore cannot explain the specific mortality sequence. Interestingly, the bark beetle attacks were also noted in two additional trees in the stand in 2017. One of these trees died, while the other one survived showing similar DBH responses in the living vs. the dying trees (i.e.- decrease in DBH during the wet season of the dying tree), as shown above (data not shown). It seems likely, therefore, that the bark beetle damage was not part of the drought-induced mortality development discussed above but could have been the last phase in the described mortality sequence.

Seeking the 'point of no return' main trait/s

There is aggregating evidence from recent studies that emphasizes the fact that hydraulic stress leading to runaway cavitation and loss of conductivity is not the single cause of tree death (Sevanto et al. , 2014; Blackman et al. , 2019). Our results support the view that the coordination of several traits leads trees to an irrecoverable state, and that this suites of interacting traits must be taken into consideration when 
considering the sequences leading up to tree mortality, including stem drying and shrinkage, embolism, and cessation of phloem radial flow.

Furthermore, our results indirectly suggest that the capability of trees to transfer water radially, e.g., from the bark and phloem to the xylem, may be critical for resilience to drought. The exact 'point of no return' in the steps leading to final mortality (Fig. 6) cannot be categorically determined in this study since this natural sequence of mortality was not linked to a recovery study, as would be initiated by experimental watering earlier than the following rainy season. However, we suggest the cessation of daily stem fluctuations as a likely key trait in the 'point of no return' definition. Radial water transport may also be linked to damage to the phloem transport and can lead to carbon limitations, and damage to the roots, and further contribute to critical steps leading to mortality (Mencuccini et al. , 2015). The evident effects of the direct damage to the phloem can also harm the phloem transport coupled to the hydraulic failure. This is supporting the idea that the mortality process is an integrative process linking hydraulic, carbon limitations, and tree's ability to develop new xylem (e.g., McDowell et al., 2008; Améglio et al. , 2002; Spicer \& Groover, 2010; Hammond et al. , 2019).

The results discussed above seem to indicate that ultimate mortality could be implied when water uptake by the tree ceased. This, in turn, could be brought about in two ways: 1) sap flow stopped due to embolism damage as a consequence of air infiltration via the de-hydrated bark and phloem tissues; or/and 2) phloem transport failure led to damage to roots reducing water uptake and inducing xylem embolism. These two scenarios are likely to coexist, and it maybe inconsequential to rank their contribution. Eventually, the cascade of events identified in this study led to the lack of response to the renewed water supply in the following rainy season, and complete failure of the xylem water transport identified by February 2016. This was nearly four months prior to visual mortality.

The sequence of steps leading to tree mortality (Fig. 6), and the definition of tree mortality itself has been investigated over at least the last decade (McDowell et al. , 2008; Sala et al. , 2010; Sevanto et al. , 2014; Garcia-Forner et al. , 2016b; Adamset al. , 2017) and yet, our understanding is still limited. This case study using a naturally occurring mortality events and in-situ measurements may help advance our understanding of the the steps, and in particular the role of radial water movement and phloem transport, leading to mortality of mature trees. Such knowledge can help identify the key traits to seek in our management attempts to reduce the impact of forest mortality. It should also motivate research to identify the factors that contribute to the extreme spatial heterogeneity in tree mortality, even within the same uniform stand, such as due to small-scale variations in the sub-surface conditions to which individual trees are exposed (Preisler et al., 2019).

\section{Acknowledgments}

The work was financially supported by KKL (project number: 90-10-012-11), and the United States-Israel binational agriculture research and development fund (BARD) grant number- FI-584-2019. We want to thank AS, BH, NMH and members of our lab for valuable discussions and comments to the manuscript.

\section{Reference}

Adams HD, Luce CH, Breshears DD, Allen CD, Weiler M, Hale VC, Smith AMS, Huxman TE . 2012 . Ecohydrological consequences of drought-and infestation-triggered tree die-off: insights and hypotheses. Ecohydrology 5 : 145-159.

Adams HD, Zeppel MJB, Anderegg WRL, Hartmann H, Landhausser SM, Tissue DT, Huxman TE, Hudson PJ, Franz TE, Allen CD, et al.2017 . A multi-species synthesis of physiological mechanisms in drought-induced tree mortality. Nature Ecology and Evolution 1 : 1285-1291.

Allen CD, Breshears DD, McDowell NG . 2015. On underestimation of global vulnerability to tree mortality and forest die-off from hotter drought in the Anthropocene. Ecosphere 6 : 1-55. 
Allen CD, Macalady AK, Chenchouni H, Bachelet D, McDowell N, Vennetier M, Kitzberger T, Rigling A, Breshears DD, Hogg EH (Ted), et al. 2010 . A global overview of drought and heatinduced tree mortality reveals emerging climate change risks for forests. Forest Ecology and Management 259 : $660-684$.

Ameglio T, Bodet C, Lacointe A, Cochard H . 2002 . Winter embolism, mechanisms of xylem hydraulic conductivity recovery and springtime growth patterns in walnut and peach trees. Tree Physiology 22: 1211-1220.

Anderegg WRL, Berry J a, Field CB . 2012 . Linking definitions, mechanisms, and modeling of drought-induced tree death. Trends in plant science 17 : 693-700.

Bastin J-F, Berrahmouni N, Grainger A, Maniatis D, Mollicone D, Moore R, Patriarca C, Picard N, Sparrow B, Abraham EM . 2017 . The extent of forest in dryland biomes. Science 356 : 635-638.

Blackman CJ, Creek D, Maier C, Aspinwall MJ, Drake JE, Pfautsch S, O'Grady A, Delzon S, Medlyn BE, Tissue DT, et al.2019 . Drought response strategies and hydraulic traits contribute to mechanistic understanding of plant dry-down to hydraulic failure. Tree Physiology 39 : 910-924.

Borghetti M, Cinnirella S, Magnani F, Basilicata A, Vegetale P .1998 . Impact of long-term drought on xylem embolism and growth in Pinus halepensis Mill . : 187-195.

Breshears DD, Myers OB, Meyer CW, Barnes FJ, Zou CB, Allen CD, McDowell NG, Pockman WT . 2009 . Tree die-off in response to global change-type drought: mortality insights from a decade of plant water potential measurements. Frontiers in Ecology and the Environment 7 : 185-189.

Brodribb TJ, Cochard H . 2009 . Hydraulic Failure Defines the Recovery and Point of Death in WaterStressed Conifers. Plant Physiology 149 : 575-584.

Cailleret M, Jansen S, Robert EMR, Desoto L, Aakala T, Antos JA, Beikircher B, Bigler C, Bugmann H, Caccianiga M, et al.2017. A synthesis of radial growth patterns preceding tree mortality. Global Change Biology 23 : 1675-1690.

Cermak J, Nadezhdina N . 1998 . Sapwood as the scaling parameter-defining according to xylem water content or radial pattern of sap flow? In: Annales des Sciences forestieres. EDP Sciences, 509-521.

Choat B, Jansen S, Brodribb TJ, Cochard H, Delzon S, Bhaskar R, Bucci SJ, Feild TS, Gleason SM, Hacke UG, et al. 2012. Global convergence in the vulnerability of forests to drought. Nature 491 : $752-755$.

Cochard H . 2019. A new mechanism for tree mortality due to drought and heatwaves.

Cohen Y, Cohen S, Cantuarias-Aviles T, Schiller G .2008 . Variations in the radial gradient of sap velocity in trunks of forest and fruit trees. Plant and Soil 305 : 49-59.

Colangelo M, Camarero JJ, Borghetti M, Gazol A, Gentilesca T, Ripullone F . 2017 . Size Matters a Lot: Drought-Affected Italian Oaks Are Smaller and Show Lower Growth Prior to Tree Death.Frontiers in Plant Science 8 : 1-14.

Coussement JR, De Swaef T, Lootens P, Roldan-Ruiz I, Steppe K .2018 . Introducing turgordriven growth dynamics into functional-structural plant models. Annals of botany121 : 849-861.

Daudet FA, Ameglio T, Cochard H, Archilla O, Lacointe A .2005 . Experimental analysis of the role of water and carbon in tree stem diameter variations. Journal of Experimental Botany56 : 135-144.

Delzon S, Cochard H . 2014 . Recent advances in tree hydraulics highlight the ecological significance of the hydraulic safety margin. New Phytologist 203 : 355-358. 
Devine WD, Harrington CA . 2011 . Factors affecting diurnal stem contraction in young Douglas-fir. Agricultural and Forest Meteorology 151 : 414-419.

Dobbertin M, Wermelinger B, Bigler C, Burgi M, Carron M, Forster B, Gimmi U, Rigling A . 2007 . Linking increasing drought stress to Scots pine mortality and bark beetle infestations. TheScientific WorldJournal 7 Suppl 1 : 231-9.

Fernandez JE, Cuevas M V . 2010. Irrigation scheduling from stem diameter variations : A review. Agricultural and Forest Meteorology 150 : 135-151.

Garcia-Forner N, Adams HD, Sevanto S, Collins AD, Dickman LT, Hudson PJ, Zeppel MJB, Jenkins MW, Powers H, Martinez-Vilalta J,et al. 2016a . Responses of two semiarid conifer tree species to reduced precipitation and warming reveal new perspectives for stomatal regulation. Plant Cell and Environment 39 : 38-49.

Garcia-Forner N, Sala A, Biel C, Save R, Martinez-Vilalta J .2016b . Individual traits as determinants of time to death under extreme drought in Pinus sylvestris L. Tree Physiology36 : 1196-1209.

Grossiord C, Sevanto S, Adams HD, Collins AD, Dickman LT, McBranch N, Michaletz ST, Stockton EA, Vigil M, McDowell NG .2017 . Precipitation, not air temperature, drives functional responses of trees in semi-arid ecosystems. Journal of Ecology 105 : 163-175.

Grunzweig JM, Gelfand I, Fried Y, Yakir D . 2007 . Biogeochemical factors contributing to enhanced carbon storage following afforestation of a semi-arid shrubland. Biogeosciences4 : 891-904.

Hammond WM, Adams HD . 2019 . Dying on time: traits influencing the dynamics of tree mortality risk from drought. Tree Physiology 39 : 906-909.

Hammond WM, Yu K, Wilson LA, Will RE, Anderegg WRL, Adams HD .2019 . Dead or dying? Quantifying the point of no return from hydraulic failure in drought-induced tree mortality. New Phytologist $: 0-3$.

Hartmann H . 2015 . Carbon starvation during drought-induced tree mortality-are we chasing a myth?

Hartmann H, Moura CF, Anderegg WRL, Ruehr NK, Salmon Y, Allen CD, Arndt SK, Breshears DD, Davi H, Galbraith D . 2018 . Research frontiers for improving our understanding of droughtinduced tree and forest mortality. New Phytologist 218 : 15-28.

Hartmann H, Ziegler W, Trumbore S . 2013 . Lethal drought leads to reduction in nonstructural carbohydrates in Norway spruce tree roots but not in the canopy. Functional Ecology27 : 413-427.

Hoch G . 2015 . Carbon reserves as indicators for carbon limitation in trees. In: Progress in botany. Springer, 321-346.

Holtta T, Linkosalo T, Riikonen A, Sevanto S, Nikinmaa E .2015 . An analysis of Granier sap flow method, its sensitivity to heat storage and a new approach to improve its time dynamics.Agricultural and Forest Meteorology $211-212: 2-12$.

Holtta T, Makinen H, Nojd P, Makela A, Nikinmaa E .2010 . A physiological model of softwood cambial growth. Tree Physiology 30 : 1235-1252.

Holtta T, Mencuccini M, Nikinmaa E . 2009 . Linking phloem function to structure: Analysis with a coupled xylem-phloem transport model. Journal of Theoretical Biology .

Holtta T, Vesala T, Sevanto S, Peramaki M, Nikinmaa E .2006 . Modeling xylem and phloem water flows in trees according to cohesion theory and Munch hypothesis. Trees 20 : 67-78.

Irvine $\mathbf{J}$, Grace $\mathbf{J}$. 1997 . Continuous measurements of water tensions in the xylem of trees based on the elastic properties of wood. Planta 202 : 455-461. 
Klein T, Cohen S, Paudel I, Preisler Y, Rotenberg E, Yakir D .2016a . Diurnal dynamics of water transport, storage and hydraulic conductivity in pine trees under seasonal drought.IForest $\mathbf{9}$.

Klein T, Cohen S, Paudel I, Preisler Y, Rotenberg E, Yakir D .2016b . Diurnal dynamics of water transport, storage and hydraulic conductivity in pine trees under seasonal drought.IForest $\mathbf{9}:$ 710-719.

Klein T, Hoch G, Yakir D, Korner C . 2014a . Drought stress, growth and nonstructural carbohydrate dynamics of pine trees in a semi-arid forest. Tree physiology 34:981-992.

Klein T, Rotenberg E, Cohen-Hilaleh E, Raz-Yaseef N, Tatarinov F, Preisler Y, Ogee J, Cohen S, Yakir D . 2014b . Quantifying transpirable soil water and its relations to tree water use dynamics in a water-limited pine forest. Ecohydrology $7:$ 409-419.

Kono Y, Ishida A, Saiki S-T, Yoshimura K, Dannoura M, Yazaki K, Kimura F, Yoshimura J, Aikawa S . 2019 . Initial hydraulic failure followed by late-stage carbon starvation leads to drought-induced death in the tree Trema orientalis. Communications biology $2: 8$.

Korner C . 2019. No need for pipes when the well is dry-a comment on hydraulic failure in trees. Tree Physiology39 : 695-700.

Lamacque L, Charrier G, dos Santos Farnese F, Lemaire B, Ameglio T, Herbette S . 2020 . Drought-induced mortality: branch diameter variation reveals a point of no recovery in lavender species. Plant Physiology : pp.00165.2020.

Martin-StPaul N, Delzon S, Cochard H . 2017 . Plant resistance to drought depends on timely stomatal closure. Ecology letters 20 : 1437-1447.

McCulloh KA, Woodruff DR . 2012 . Linking stomatal sensitivity and whole-tree hydraulic architecture. Tree physiology 32 : 369-372.

McDowell NG . 2011. Mechanisms linking drought, hydraulics, carbon metabolism, and vegetation mortality. Plant physiology 155 : 1051-9.

McDowell N, Pockman WT, Allen CD, Breshears DD, Cobb N, Kolb T, Plaut J, Sperry J, West A, Williams DG, et al. 2008. Mechanisms of plant survival and mortality during drought: why do some plants survive while others succumb to drought? The New phytologist 178 : 719-39.

Meir P, Mencuccini M, Dewar RC . 2015 . Drought-related tree mortality: addressing the gaps in understanding and prediction. New Phytologist 207 : 28-33.

Mencuccini M, Minunno F, Salmon Y, Martinez-Vilalta J, Holtta T . 2015 . Coordination of physiological traits involved in drought-induced mortality of woody plants. New Phytologist 208 : 396-409.

Nardini A, Savi T, Trifilo P, Gullo MA Lo . 2017. Drought stress and the recovery from xylem embolism in woody plants. In: Progress in Botany Vol. 79. Springer, 197-231.

Ogaya R, Barbeta A, Başnou C, Peñuelas J . 2015 . Satellite data as indicators of tree biomass growth and forest dieback in a Mediterranean holm oak forest. Annals of forest science 72 : 135-144.

Paz-Kagan T, Vaughn NR, Martin RE, Brodrick PG, Stephenson NL, Das AJ, Nydick KR, Asner GP . 2018 . Landscape-scale variation in canopy water content of giant sequoias during drought. Forest Ecology and Management 419 : 291-304.

Pfautsch S, Hölttä T, Mencuccini M . 2015a . Invited review Hydraulic functioning of tree stems fusing ray anatomy, radial transfer and capacitance. : 706-722.

Pfautsch S, Renard J, Tjoelker MG, Salih A . 2015b . Phloem as capacitor: Radial transfer of water into xylem of tree stems occurs via symplastic transport in ray parenchyma. Plant Physiology 167 : 963-971. 
Preisler Y, Tatarinov F, Grünzweig JM, Bert D, Ogée J, Wingate L, Rotenberg E, Rohatyn S, Her N, Moshe I, et al. 2019 . Mortality versus survival in drought-affected Aleppo pine forest depends on the extent of rock cover and soil stoniness. Functional Ecology 33 : 901-912.

Pugh TAM, Arneth A, Kautz M, Poulter B, Smith B . 2019 . Important role of forest disturbances in the global biomass turnover and carbon sinks. Nature geoscience : 1-6.

Rotenberg E, Yakir D . 2010 . Contribution of semi-arid forests to the climate system. Science (New York, N.Y.)327 : 451-4.

Sala A, Piper F, Hoch G . 2010 . Physiological mechanisms of drought-induced tree mortality are far from being resolved. New Phytologist 186 : 274-281.

Sala A, Woodruff DR, Meinzer FC . 2012 . Carbon dynamics in trees: feast or famine? Tree physiology 32: 764-775.

Salmon Y, Dietrich L, Sevanto S, Holtta T, Dannoura M, Epron D .2019 . Drought impacts on tree phloem: From cell-level responses to ecological significance. Tree Physiology 39 : 173-191.

Sapes G, Roskilly B, Dobrowski S, Maneta M, Anderegg WRL, Martinez-Vilalta J, Sala A . 2019 . Plant water content integrates hydraulics and carbon depletion to predict drought-induced seedling mortality. Tree physiology 39 : 1300-1312.

Savage JA, Clearwater MJ, Haines DF, Klein T, Mencuccini M, Sevanto S, Turgeon R, Zhang C . 2016 . Allocation, stress tolerance and carbon transport in plants: how does phloem physiology affect plant ecology? Plant, Cell \& Environment 39 : 709-725.

De Schepper V, Steppe K . 2010 . Development and verification of a water and sugar transport model using measured stem diameter variations. Journal of Experimental Botany 61 : 2083-2099.

Scholz FC, Bucci SJ, Goldstein G, Meinzer FC, Franco AC, Miralles-Wilhelm F . 2008 . Temporal dynamics of stem expansion and contraction in savanna trees: withdrawal and recharge of stored water. Tree Physiology 28 : 469-480.

Schultz JC, Appel HM, Ferrieri A, Arnold TM . 2013. Flexible resource allocation during plant defense responses. Frontiers in plant science $4: 324$.

Schwantes AM, Swenson JJ, Jackson RB . 2016 . Quantifying drought-induced tree mortality in the open canopy woodlands of central Texas. Remote sensing of environment 181 : 54-64.

Sevanto S, Holtta T, Holbrook NM . 2011 . Effects of the hydraulic coupling between xylem and phloem on diurnal phloem diameter variation. Plant, Cell and Environment 34 : 690-703.

Sevanto S, Mcdowell NG, Dickman LT, Pangle R, Pockman WT .2014. How do trees die? A test of the hydraulic failure and carbon starvation hypotheses. Plant, Cell and Environment37 : 153-161.

Sevanto S, Vesala T, Peramaki M, Nikinmaa E . 2002 . Time lags for xylem and stem diameter variations in a Scots pine tree.Plant, Cell $\&$ Environment 25 : 1071-1077.

Sperry JS, Love DM . 2015 . What plant hydraulics can tell us about responses to climate-change droughts. New Phytologist 207 : 14-27.

Spicer R, Groover A . 2010 . Evolution of development of vascular cambia and secondary growth. New Phytologist186 : 577-592.

Steppe K, Sterck F, Deslauriers A . 2015 . Diel growth dynamics in tree stems: Linking anatomy and ecophysiology. Trends in Plant Science.

De Swaef T, De Schepper V, Vandegehuchte MW, Steppe K .2015 . Stem diameter variations as a versatile research tool in ecophysiology. Tree Physiology 35 : 1047-1061. 
Tatarinov FA, Kučera J, Cienciala E . 2005. The analysis of physical background of tree sap flow measurement based on thermal methods. Measurement science and Technology 16 : 1157.

Tatarinov F, Rotenberg E, Maseyk K, Ogée J, Klein T, Yakir D .2016 . Resilience to seasonal heat wave episodes in a Mediterranean pine forest. New Phytologist 210 : 485-496.

Tyree MT, Sperry JS . 1988 . Do woody plants operate near the point of catastrophic xylem dysfunction caused by dynamic water stress?: answers from a model. Plant physiology 88 : 574-580.

Tyree MT, Sperry JS . 1989 . Vulnerability of xylem to cavitation and embolism. Annual review of plant biology $40: 19-36$.

Urrutia-Jalabert R, Rossi S, Deslauriers A, Malhi Y, Lara A .2015 . Environmental correlates of stem radius change in the endangered Fitzroya cupressoides forests of southern Chile.Agricultural and Forest Meteorology 200 : 209-221.

Vergeynst LL, Vandegehuchte MW, McGuire MA, Teskey RO, Steppe K . 2014 . Changes in stem water content influence sap flux density measurements with thermal dissipation probes. Trees - Structure and Function 28 : 949-955.

Wiley E, Hoch G, Landhäusser SM . 2017 . Dying piece by piece: carbohydrate dynamics in aspen (Populus tremuloides) seedlings under severe carbon stress. Journal of experimental botany68: 5221-5232.

Zweifel R . 2016 . Radial stem variations - a source of tree physiological information not fully exploited yet. Plant, Cell and Environment 39 : 231-232.

Zweifel R, Drew DM, Schweingruber F, Downes GM . 2014 . Xylem as the main origin of stem radius changes in Eucalyptus. Functional Plant Biology 41 : 520-534.

Zweifel R, Haeni M, Buchmann N, Eugster W . 2016. Are trees able to grow in periods of stem shrinkage? New Phytologist211 : 839-849.

Zweifel R, Häsler R . 2000 . Stem radius changes and their relation to stored water in stems of young Norway spruce trees. Trees $15: 50-57$.

Zweifel R, Item H, Häsler R . 2001 . Link between diurnal stem radius changes and tree water relations. Tree Physiology 21 : 869-877.

\section{Hosted file}

Figure 1.docx available at https://authorea.com/users/358352/articles/480535-seeking-thepoint-of-no-return-in-the-sequence-of-events-leading-to-mortality-of-mature-trees

\section{Hosted file}

Figure 2.docx available at https://authorea.com/users/358352/articles/480535-seeking-thepoint-of-no-return-in-the-sequence-of-events-leading-to-mortality-of-mature-trees

\section{Hosted file}

Figure 3.docx available at https://authorea.com/users/358352/articles/480535-seeking-thepoint-of-no-return-in-the-sequence-of-events-leading-to-mortality-of-mature-trees

\section{Hosted file}

Figure 4.docx available at https://authorea.com/users/358352/articles/480535-seeking-thepoint-of-no-return-in-the-sequence-of-events-leading-to-mortality-of-mature-trees

\section{Hosted file}

Figure 5.docx available at https://authorea.com/users/358352/articles/480535-seeking-thepoint-of-no-return-in-the-sequence-of-events-leading-to-mortality-of-mature-trees 


\section{Hosted file}

Table 1.docx available at https://authorea.com/users/358352/articles/480535-seeking-thepoint-of-no-return-in-the-sequence-of-events-leading-to-mortality-of-mature-trees

Hosted file

Figure 6.docx available at https://authorea.com/users/358352/articles/480535-seeking-thepoint-of-no-return-in-the-sequence-of-events-leading-to-mortality-of-mature-trees 